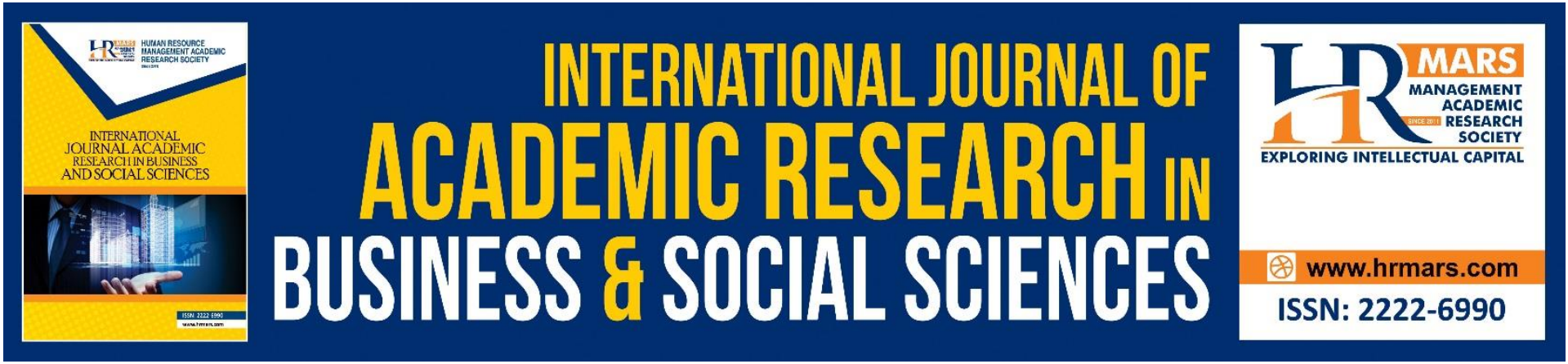

\title{
Assessing Business Process Re-Engineering Warning Signs and Organizational Performance: A Case Study of Perbadanan Kemajuan Pertanian Pahang, Malaysia
}

Zuria Akmal Saad, Mohd Amli Abdullah, Mohd Zulkifli Abdullah and Zaidatulhusna Isnani

To Link this Article: http://dx.doi.org/10.6007/IJARBSS/v11-i11/11192 DOI:10.6007/IJARBSS/v11-i11/11192

Received: 06 September 2021, Revised: 01 October 2021, Accepted: 21 October 2021

Published Online: 06 November 2021

In-Text Citation: (Saad et al., 2021)

To Cite this Article: Saad, Z. A., Abdullah, M. A., Abdullah, M. Z., \& Isnani, Z. (2021). Assessing Business Process Re-Engineering Warning Signs and Organizational Performance: A Case Study of Perbadanan Kemajuan Pertanian Pahang, Malaysia. International Journal of Academic Research in Business and Social Sciences, 11(11), 79-90.

Copyright: (C) 2021 The Author(s)

Published by Human Resource Management Academic Research Society (www.hrmars.com)

This article is published under the Creative Commons Attribution (CC BY 4.0) license. Anyone may reproduce, distribute, translate and create derivative works of this article (for both commercial and non-commercial purposes), subject to full attribution to the original publication and authors. The full terms of this license may be seen

at: http://creativecommons.org/licences/by/4.0/legalcode

Vol. 11, No. 11, 2021, Pg. $79-90$

http://hrmars.com/index.php/pages/detail/IJARBSS

JOURNAL HOMEPAGE

Full Terms \& Conditions of access and use can be found at http://hrmars.com/index.php/pages/detail/publication-ethics 


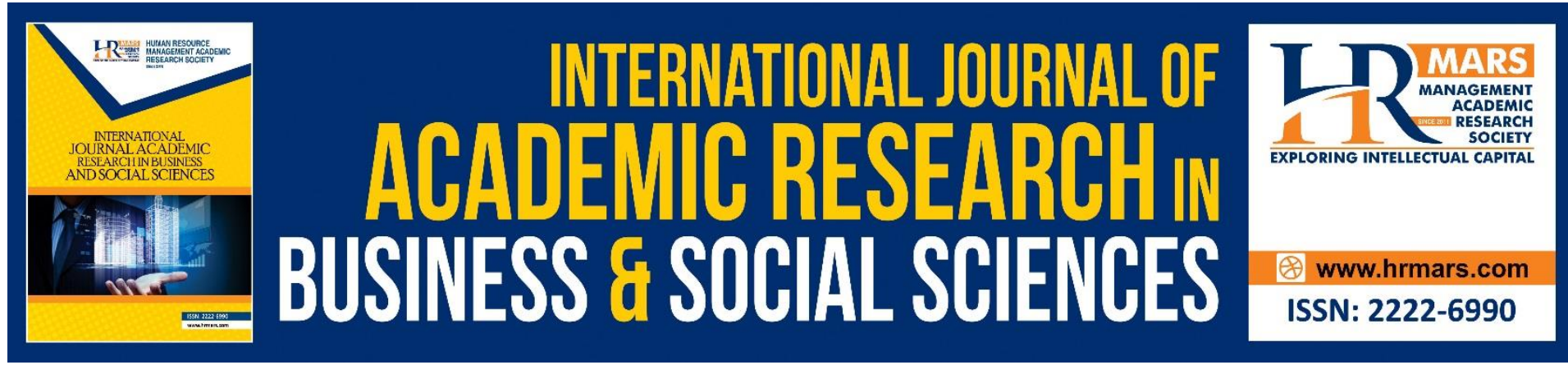

\title{
Assessing Business Process Re-Engineering Warning Signs and Organizational Performance: A Case Study of Perbadanan Kemajuan Pertanian Pahang, Malaysia
}

\author{
Zuria Akmal Saad ${ }^{1}$, Mohd Amli Abdullah ${ }^{1}$, Mohd Zulkifli \\ Abdullah $^{2}$ and Zaidatulhusna Isnani ${ }^{3}$ \\ ${ }^{1}$ Faculty of Business and Management, Universiti Teknologi MARA Pahang, Bandar Tun \\ Abdul Razak Jengka, Pahang, Malaysia, ${ }^{2}$ Faculty of Business and Management, Universiti \\ Teknologi MARA Selangor, 42300 Puncak Alam, Malaysia, ${ }^{3}$ Faculty of Business and \\ Management, Universiti Teknologi MARA Negeri Sembilan, 70300 Kampus Seremban, \\ Malaysia \\ Email:zuria@uitm.edu.my, amli_baharum@uitm.edu.my,m_zulkifli@uitm.edu.my, \\ husna@uitm.edu.my
}

\begin{abstract}
Organizational change - be it moderate or radical - is a must for a better future. Situations such as increasing demands of government regulations, growth, competition, technological developments and changing workforce cause organizations to change. Perbadanan Kemajuan Pertanian Negeri Pahang is one of the biggest organizations in Pahang Darul Makmur. Operating for more than 49 years and has more than 116 staff in the organization, the main headquarters need to deliver the right business process not only to external but internal customers as well. Due to the political and economic change recently, it is important for the organization to stay competitive for the future. The present study aims to examine the Business Process Re-engineering (henceforth BPR) warning signs in the process, technology, and organizational structure as well as company performance. A total of 56 responses collected from the respondents were analyzed, and the findings indicated that all the warning signs do not affect the company's performance. The implications of the study are further discussed in the paper.
\end{abstract}

Keywords: Business Process Re-engineering, Company Performance, Organization Structure, Process, and Technology.

\section{Introduction}

Today's current situation requires an organization to be more competitive than ever. Relentless customers, competition among companies and change in the environment were among the factors that an organization need to reengineer (O'neil and Sohal, 1999). However, not all companies implementing Business Process Re-engineering (BPR) achieved 
the result they aimed for. On top of that, BPR assessment has become a company agenda in implementing BPR projects (Hagos, 2012). Kleiner (2000) reported that $70 \%$ of BPR projects were unsuccessful. The problem is that those companies knew they need to change but did not know where and how to do to it. This has led to the projects being implemented without proper planning (Covert, 1997).

There are many causes of project failure, and one of the causes is not understanding BPR concept thoroughly. BPR projects can only be initiated when the company is ready. The key to the success of BPR projects depends on organizational readiness (Hussain et al., 2014). There are many steps and methods that have been suggested in implementing BPR projects but no one method can fit all organizations. BPR method can only serve as guidelines in implementing BPR projects (Hussain, et al., 2014). Many scholars agree that BPR is doing business in a new way. Redesigning a business process creates a new way for company to perform and gives a drastic impact to company performance in terms of cost, speed and service (Adeyemi \& Aremu, 2008). In order for the company to become effective and efficient, company performance depends on business processes and procedures. Business processes and procedures are the main factors to give the best to customers. However, company cannot stay competitive and cope with the environment if the business processes and procedures are obsolete (Amanquah and Adjei, 2016).

A study by O'Neill and Sahol (1999) mentioned that there were three signs that company needs to be aware of. The first is company performance, for example cost, bad customer service and product failure. The second sign is the worker who will see the trouble in the organization even though the organization is doing fine, and the last sign is the organization that wants to develop or be more competitive than its competitors.

Perbadanan Kemajuan Pertanian Negeri Pahang (PKPNP) is one of the biggest organizations in Pahang Darul Makmur. It serves eight sub companies in many fields such as agriculture, plantation, property and resort. Operating for more than 49 years and has more than 116 staff in the organization, the main headquarters need to deliver the right business process not only to external customers but internal customers as well. Due to the political and economic change recently, it is important for the organization to stay competitive for the future. According to Kotter and Schlesigner (1979), organizational change is a must for a better future be it moderate or radical. Situations such as increasing demands of government regulations, growth, competition, technological developments and changing workforce cause organizations to change. This study initial attempts to evaluate BPR dimensions towards organizational performance. The objectives of this study are:

i. to investigate the current performance level in the process, technology and organizational structure,

ii. to identify which dimension of BPR (process, technology and organizational structure) has potential for improvement, and

iii. to identify the relationship between the dimension of BPR and overall organizational performance.

This study however, is only limited to PKPP staff and only the first (physical) layer of BPR which are process structure, technology structure and organizational structure will be covered. 


\section{Literature Review}

Business Process Re-engineering

Designing business process was introduced in early 1980. The idea of designing new business process arises because of the service-oriented nature of businesses nowadays. People and process are the factors that create service (Lilian, Uzochukwu \& Francisca, 2015). Even though there are a lot of management techniques that have been introduced to increase organizational performance, it has been proven that BPR can bring dramatic impacts to organization's survival and success (Sungau, Ndunguru \& Kimeme, 2013). BPR concept is studying the current business process and eliminating redundancy and waste. By doing this, an organization is actually starting new ways of doing business (Lilian et al., 2015).

\section{Business Process}

An organization cannot perform well if the business process is not good and remains the nonvalue added to the activities. Besides, when people and process are not structured in the right way, it will lead to poor organizational performance (Lilian et, al. 2015). In implementing BPR, wrongly chosen process and objective can lead to BPR project failure and may affect organizational performance (Chan \& Choi, 1997; Goskoy, Ozsoy \& Vayvay, 2012). Set of activities to transform inputs to outputs is a simple way to define the business process. The output of business process is goods and services (Stoddard and Jarvenpea, 1995). The significance of business process is that output produced by the organization must create value to customers (Hussain et.al., 2014). Some processes are rigid and controlled but some are flexible. The problem with the business process today is that they emerge informally and spontaneously. This happened because the business process does not change when the organization needs to change. Undocumented work, inconsistent approach and employees' work attitude are amongst the signs that an organization needs BPR (Andrews and Stalick, 1994).

Information Technology

Applying Information Technology (IT) is sine qua non in BPR. Besides, it is one of the requirements that support business process to become more efficient (Adeyami, \& Aremu, 2008). IT has been viewed as the source that can bring new way of doing business by supporting business process and helping the organization to reduce cost of coordination. (Adeyemi et. al., 2008). IT also brings up the communication channel that can link business, people and organization. However, the use of technology alone does nothing to a business. The impact can only occur if the implementation fits well within the organization's environment (Hussain, et. al., 2014). A study by Amanquah, \& Adjei (2016) regarding the implementation of IT in Ghana Commercial Bank revealed that the organization did implement IT in the business process, however the result was the opposite. It was found that the investment was not equal to profit, the cost of staff increased, and the efficient use of system was less than expected where only $3 \%$ of the users utilised $75 \%$ of the system. Lack of training and resistance to change were the causes of underutilization of the system. Another problem related to the system is the reliability of the system itself. The staff rated $68 \%$ of the system is not reliable where network problem has caused them trouble to perform their duties. In overcoming the IT problem, Leavitt Diamond has listed out four variables that are necessary for BPR's success which are Information Technology, Organizational Form, People Skills and Business Process, but balancing these four elements will be difficult because it is hard to detect the warning signs that these are out of balance (Cook \& Dyer, 2003). 


\section{Organizational Structure}

Coordinating human resources and jobs in order to perform work and to achieve organization's goal is known as organizational structure. By having an organizational structure, procedures will be established to determine who makes decision and assigns various tasks in the organization. Organizational structure is important in helping the organization to achieve its goals through task allocation, coordination and supervision. It can also be the perspective of employees to see the organization and the environment. Poorly designed or poor use of organizational structure can lead to several problems in the organization such as low productivity, unequal workload, unclear line of communication, slowness in decisions making and lack of innovation (Elsaid, Okasha \& Abdelghaly, 2013). Besides, the problem with the organizational structure can also impact functional business structure. This structure divides a work into small tasks which are performed by low-skilled workers with little responsibility. Meanwhile, a trusted manager or a high-skilled worker is in charge of decision making. This results in the process being performed in a hierarchical manner which can separate workers based on their tasks. Inefficiency in business process is also caused by bureaucratic management style. This style is usually found in public sector organizations where the bureaucracy exists through checking, rechecking, approving, authorizing, storing and recording processes. When all these processes take place, it will not only reduce employees' performance, but also lead to customer dissatisfaction (Iqbal, Nadeem \& Zaheer, 2015).

\section{Organizational Performance}

Indicator of performance achieved by an organization in a certain period is known as organizational performance. Performance of a company is good when there is an improvement from the previous period's achievement. There are two ways to determine organizational performance - objective and subjective. Achieving targets, such as in financial, production, marketing and other operational activities oriented to the level of profitability, falls under objective category. Meanwhile, subjective measurement includes appraisals on how employees perform their work beyond the level set up by the organization (Hermaniwaty, 2016). Besides these two categories, a study by Xiaoming \& Junchen (2012) added two more categories which are (a) added value of intangible factors, such as management and the government, and (b) long-run development and strength of the competition. It can be concluded that in determining the performance of organization, both categories are interrelated which employees need to excel in to achieve their target and financial success (Hermaniwaty, 2016). According to Amanquah et, el. (2013), understanding BPR is significant in reforming and transforming business operations to achieve organizational performance successfully. Improving organizational performance through BPR gives a positive sign due to the integration of knowledge and empowerment of employees. Thus, the implementation of BPR should get the full commitment of all organizational members as well as the top management to completely succeed. Furthermore, the study by Jing, Pee and Junichi (2013) proved that BPR significantly influences an organizational innovation performance. Besides that, R. Selladurai, 2002 asserted that most of BPR effort will give positive impact toward improving business processes but not management process including performance measurement. However, BPR can create changes beyond structural organization. BPR can improve organizational performance by focusing more on major elements of quality, people, customers, adaptability, business processes and leadership in the organization and it will lead to increased revenues and profits (Selladurai, 2002). 


\section{Methodology}

The study is correlational in nature since it is intended to describe the relationship between business process re-engineering (BPR) warning signs and organizational performance. The sampling frame is based on a list of office workers who work at Perbadanan Kemajuan Pertanian Negeri Pahang, Malaysia (PKPNP). A total of 56 from 65 administrative workers were selected as samples for the study according to Krejcie \& Morgan (1970) table. This study applied non-contrived setting with minimal researcher interference and was conducted in single cross-sectional study in which data were gathered just once.

The questionnaire was adapted from the established questionnaires and the items were modified to suit the office workers' perspective in order to get the required responses that would answer the research questions. The questionnaire consists of several sections namely Section A to request demographic information of respondents such as age, gender, work position and work experience. Section B includes items assessing BPR warning signs such as organizational structure, work process and IT support among respondents. The survey was adapted from Andrew and Stalik, (1994) meanwhile for organizational performance it was adapted from Herminawaty (2016). The questionnaire utilized closed-ended questions with a fixed range of possible answers, using 5-point Likert scale with the following values; $1=$ strongly disagree, 2 = disagree, $3=$ uncertain, $4=$ agree and $5=$ strongly agree to measure all variables in this study.

Data were analyzed using the latest statistical software (SPSS version 24) for descriptive and inferential statistics. The descriptive statistics include the variables' mean and standard deviation. In addition, correlational analysis involves the use of inferential statistics, namely, Pearson product moment correlation coefficient. Correlation analysis is appropriate for interval scale variables and was used as it measures the relationship between variables.

\section{Results and Discussion Response Rate}

For the purpose of data collection, a total of 56 sets of questionnaire were distributed. Data were personally collected from the respective respondents. Self-administered survey technique was applied because it offers several advantages over alternative methods such as respondents answer at their convenience, there is no need to set up interview appointments, no interviewer is present to inject bias in the way questions are asked and the low cost-percompletion makes it an economical method of surveying large samples (Burns et al., 2008). After the lapse of a week, all 56 sets of questionnaire were collected, producing a response rate of $65 \%$.

\section{Demographic Information}

Respondents were asked about their gender, age, educational qualification, job position, job experience and marital status. Analyzing the gender distribution, it was slightly higher for females. The analysis of the data indicated that 31 (55.4\%) were female and 25 (44.6\%) were male respondents. As shown in Table 1, 20 of them (35.7\%) were from the age group of $20-$ 30 years old, followed by $7(12.5 \%)$ in the age group of $31-40$ years old, $16(28.6 \%)$ of them from $41-50$ and 13 (23.2\%) of them from 50 and above of age.

Exploring the sampling distribution based on educational qualification, most of the 
respondents have SPM as their highest education level as represented by 28 (50\%), 10 (17.9\%) of them have Diploma, while 18 (32.1\%) have other qualifications such as certificate from polytechnic college.

In the context of the respondents' experience in their current position at the workplace, it was found that $7(12.5 \%)$ of them had working experience of between $6-10$ years and 16 (28.6\%) of them had working experience of $1-5$ years. 26 (46.4\%) of them had working experience of more than 10 years while only 7 of them (12.5\%) had working experience of less than 1 year.

Table 1: Profile of Respondents ( $n=56$ )

\begin{tabular}{llll}
\hline Demographic Information & Frequency & Percent \\
\hline Gender & Male & 25 & 44.6 \\
Female & & 31 & 55.4 \\
Total & & 56 & 100.0 \\
& & & \\
Age (years) & $20-30$ & 7 & 35.7 \\
$31-40$ & & 16 & 12.5 \\
& $41-50$ & 13 & 28.6 \\
& $51-60$ & 56 & 23.2 \\
& Total & & 100.0
\end{tabular}

\begin{tabular}{llll}
$\begin{array}{lll}\text { Education } \\
\text { Level }\end{array}$ & Diploma & 10 & 17.9 \\
& SPM & 28 & 50.0 \\
& Others & 18 & 32.1 \\
& Total & 56 & 100.0 \\
Working & Less than 1 year & 7 & \\
Experience & $1-5$ & 16 & 12.5 \\
(Years) & $6-10$ & 7 & 28.6 \\
& More than 10 years & 26 & 12.5 \\
& Total & 56 & 46.4 \\
& & & 100.0 \\
\hline
\end{tabular}

\section{Normality Results}

An assessment of the normality of data is a prerequisite for many statistical tests because normal data is an underlying assumption in parametric testing. In statistics, normality tests are used to determine if a data set is well-modeled by a normal distribution and to compute how likely it is for a random variable underlying the data set to be normally distributed. More precisely, the tests are a form of model selection, and can be interpreted in several ways, depending on one's interpretations of probability (Hair, 2010). In this study, normality test was measured using Skewness and Kurtosis. According to Hair (2010), normal distribution of data should range between -1.82 to 1.82 only. As illustrated in Table 2, all variables show the value of Skewness and Kurtosis between -1.81 to 1.77, therefore, it can be concluded that the data of this study is normally distributed. 
Table 2: Normality Results ( $n=56$ )

\begin{tabular}{|l|l|l|}
\hline Variables & Skewness & Kurtosis \\
\hline Organizational Structure & -1.1 & 1.72 \\
\hline Work Process & -1.81 & 1.79 \\
\hline IT Support & -.71 & 1.51 \\
\hline Organizational Performance & -1.05 & 1.77 \\
\hline
\end{tabular}

\section{Reliability Results}

For the quantitative method, the reliability of the questionnaire was analyzed by using the Cronbach's Alpha technique from SPSS Version 24. According to Santos (1999), Cronbach's Alpha is a measure of squared correlation between observed scores and true score. The internal consistency was measured by Cronbach's Alpha and it is noted that a reliability coefficient of 0.70 or higher is considered acceptable in most social-science research situations (Santos, 1999). The purpose is to ensure that the items in the survey questionnaire are consistent in measuring the variables of the study (Sekaran, 2000).

Table 3 illustrates the reliability analysis based on the four variables in this study which consist of organizational structure, work process, IT support and organizational performance. The Cronbach's Alpha value for organizational structure is .92 with 5 items, work process is .72 17 items, IT support is .9 with 6 items, and organizational performance is .92 with 8 items. It can be concluded that the instruments in this study are reliable for further analysis.

Table 3: Reliability Results ( $n=56$ )

\begin{tabular}{|l|l|l|}
\hline Variables & Cronbach's Alpha & N of Item \\
\hline Organizational Structure & .92 & 5 \\
\hline Work Process & .72 & 17 \\
\hline IT Support & .90 & 6 \\
\hline Organizational Performance & .92 & 8 \\
\hline
\end{tabular}

\section{Mean, Standard Deviation and Correlation Results}

Table 4 provides the composite of the perception of organizational structure. From the results, the mean score for organizational structure as rated by the respondents is 3.78 $(S D=.69)$. It indicates that most respondents agreed and were satisfied with the organizational structure implemented in their organization such as simple organizational structure, clear job accountability among workers, clear job reporting relationship, position among workers are based on job skill and knowledge requirement and clear departmental roles and responsibility.

Table 4 below also presents the results of the mean score and standard deviation of perception on work process as reported by respondents. As can be seen from the results, the mean score for work process is $3.56(S D=.68)$, indicating that most of the respondents agreed that they were satisfied with work process practiced in their organization such efficient and no time delay process, work process in control, flexible work process, no facility problems in work processing and no duplication of work.

Further analysis showed that, the mean score for IT support is 3.81 ( $S D=.69$ ), signifying that most of the respondents claimed that they were satisfied with the system and technology 
provided in their organization. They agreed that system and technology support can make them work efficiently, make it easy to access an information, have no problem in data creation, updating and deleting, and provide reliable input from the system.

In addition, the result obtained from Table 4 also presents the mean score for organizational performance with 3.86 ( $\mathrm{SD}=.571$ ). It means that most of the respondents agreed that their organization is in good performance such as achieving good financial performance, achieving yearly Key Performance Indicators (KPIs), focusing on customer satisfaction and value added activity, always looking for process improvement, applying the right technology as well as having less customer complaint.

The results of this study showed that there are no warning signs that showed the company need to implement BPR. However as mentioned by O'Neill and Sohal (1999), there are three signs that company needs to be aware of and one of them is if a company wants to stay competitive, the implementation of BPR should be considered. Based on the results, the perceptions for the process, organizational structure and IT support were at moderate level. This shows that the respondents were only satisfied with the process, organizational structure and IT support and improvement can be made by the organization. From the result, work process showed the lowest level among the three warning signs for BPR. Business process plays a vital role in organizational performance. This aligns with the study by Amanquah and Adjei (2016) which revealed that in order for the company to become effective and efficient, company's performances are depending on business processes and procedures. The business processes and procedures are the main factor to give the best to the customer. However, company can't stay competitive and cope with the environment if the business processes and procedures are obsolete. Even though there is no warning sign that exist in the company, a change can be implemented for the future if and when needed. This can be supported by Kotter and Schlesigner (1979) who mentioned that change is a must for organization whether it is moderate or radical change. As the implementation of BPR itself is a radical change, perhaps PKPP can do a moderate change in the organization for better performance in the future.

Table 4: Mean Score, Standard Deviation and Correlation Results ( $n=56)$

\begin{tabular}{|l|l|l|l|l|l|l|l|}
\hline No & Variables & Mean & SD & $\mathbf{1}$ & $\mathbf{2}$ & $\mathbf{3}$ & $\mathbf{4}$ \\
\hline 1 & Organizational Structure & 3.78 & .69 & 1 & $.642^{* *}$ & $.854^{* *}$ & $.846^{* *}$ \\
\hline 2 & Work Process & 3.56 & .68 & $.642^{* *}$ & 1 & $.606^{* *}$ & $.661^{* *}$ \\
\hline 3 & IT Support & 3.81 & .69 & $.854^{* *}$ & $.606^{* *}$ & 1 & $.715^{* *}$ \\
\hline 4 & Organizational Performance & 3.86 & .571 & $.846^{* *}$ & $.661^{* *}$ & $.715^{* *}$ & 1 \\
\hline
\end{tabular}

Notes: ${ }^{* *}$. Correlation is significant at the 0.01 level (1-tailed)

Table 5: Guilford's Rule of Thumb

\begin{tabular}{|l|l|}
\hline$r$ & Strength of Relationship \\
\hline$<0.20$ & Almost negligible relationship \\
$0.20-0.40$ & Low correlation; definite but small relationship \\
$0.40-0.70$ & Moderate correlation; substantial relationship \\
$0.70-0.90$ & High correlation; marked relationship \\
$>0.90$ & Very high correlation; very dependable relationship \\
\hline
\end{tabular}




\section{Conclusion}

In today's competitive world, change is a must for the organization. Through the right implementation of BPR, organizations can earn the benefits that they aimed for. This paper measures the first layer of the BPR dimension and organizational performance. Three first layer of BPR dimensions that are used in this study are the process, technology, and organizational structure. Each of these dimensions is important in order to ensure the business is in a "right alignment" for better organizational performance. Overall, it can be concluded that respondents from PKPNP are satisfied with the organizational performance of their organization. The process design in the organization is in the right way, clear of organizational structure in defining roles and responsibilities, and the IT system that implemented in the organization support the business process effectively. Consequently, aligning these three dimensions is a good sign for organizational performance. Even though there are no warning signs that occurs in the organization, improvement should be continuously made especially in terms of the work process as it is the main contribution to the organizational performance.

\section{Recommendations}

As this study only focused on Perbadanan Kemajuan Pertanian Negeri Pahang as population of the study, other researches can be extended to different population. The extension of the study will distinguish the different results captured in different organizations. Comparison can be made and finding can distinguish problems faced by different organizations. Future studies are also recommended to study the different layers of BPR as this study only focused on the first (physical) layer. Other layers that can be studied are infrastructure layer that consists of reward structure, measurement systems and management methods; and value layer that consists of organizational culture, political power and individual belief systems.

\section{References}

Adeyami, S., \& Aremu, M. A. (2008). Impact Assessment of Business Process Reengineering on Organizational Performance. European Journal of Social Sciences - Volume 7, Number 1. Retrieved from https://pdfs.semanticscholar.org/eb90/9f23c754fd109b13fa343da6c2e5e27bb90c.pdf

Amanquah, B., \& Adjei, K. S. (2016). Business Process Reengineering (BPR) In the Financial Services Sector: A Case Study of Ghana Commercial Bank (GCB) Limited. European Journal of Business and Management. Vol.5, No.29. Retrieved from http://connection.ebscohost.com/c/articles/94436860/business-processreengineering-bpr-financial-services-sector-case-study-ghana-commercial-bank-gcblimited

Burns, K. E., Duffett, M., Kho, M. E., Meade, M. O., Adhikari, N. K., Sinuff, T., \& Cook, D. J. (2008). A guide for the design and conduct of self-administered surveys of clinicians. Canadian Medical Association Journal, 179(3), 245-252.

Cook, G. R., \& Dyer, J. D. (2003). Business process reengineering with knowledge value added in support of the department of the navy chief information officer. NAVAL POSTGRADUATE SCHOOL MONTEREY CA.

Covert, M. (1997). Successfully Performing BPR. Retrieved from http://www.ies.aust.com/papers/BPR.html

Elsaid, N. M., Ahmed, E., Okasha, A. E., \& Abdalla A. A. (2013). Defining and Solving the Organizational Structure Problems to Improve the Performance of Ministry of State for 
Environmental Affairs - Egypt. International Journal of Scientific and Research Publications, Volume 3, Issue 10. Retrieved from http://www.ijsrp.org/research-paper1013/ijsrp-p2244.pdf

Goskoy, A., Oszoy, B., \& Vayvay, O. (2012). Business Process Reengineering: Strategic Tool for Managing Organizational Change an Application in a Multinational Company. International Journal of Business and Management Vol. 7, No. 2. Retrieved from https://www.researchgate.net/publication/267250206_Business_Process_Reengineer ing_Strategic_Tool_for_Managing_Organizational_Change_an_Application_in_a_Multi national_Company

Guilford, J. P. (1956). The Guilford-Zimmerman Aptitude Survey. The personnel and guidance journal, 35(4), 219-223.

Hair, J. F., Black, W. C., Babin, B. Y. A., Anderson, R., \& Tatham, R. (2010). RE [2010]: Multivariate Data Analysis. A Global Perspective

Hagos, S. (2012). Assessment of Business Process Reengineering Implementation and Result within Ethiopian Ministry of Health and Gambella Regional Health Bureau Contexts. Retrieved from http://bth.diva-portal.org/smash/record.jsf?pid=diva2:832686

Abubakar, H. (2016). Effects of Business Process Reengineering on Organizational Performance: Organizational Transformation of Tour and Travel Business. Asian Journal of Applied Sciences (ISSN: 2321 - 0893) Volume 04 - Issue 01. Retrieved from https://www.researchgate.net/publication/323656562_Effects_of_Business_Process_ Reengineering_on_Organizational_Performance_Organizational_Transformation_of_T our_and_Travel_Business

Hussain, M., Saleh, M., Akbar, S., \& Jan, Z. (2014). Factors Affecting Readiness for Business Process Reengineering- Developing and Proposing a Conceptual Model. European Journal of Business and Management. Vol.6, No.1. Retrieved from https://www.iiste.org/Journals/index.php/EJBM/article/view/10208

lqbal, N., Nadeem, W., \& Zaheer, A. (2015). Impact of BPR critical success factors on interorganizational functions: an empirical study. The Business \& Management Review, Volume 6, Number 1. Retrieved from

https://www.researchgate.net/publication/316472740_Impact_of_BPR_critical_succe ss_factors_on_inter-organizational_functions_An_empirical_study

Kleiner, A. (2000). Revisiting reengineering. Strategy+ Business, 20(3), 27-31.

Krejcie, R. V., \& Morgan, D. W. (1970). Determining sample size for research activities. Educational and psychological measurement, 30(3), 607-610.

Kotter, J. P., \& Schlesinger, L. A. (1979). Choosing strategies for change. Harvard Business Review, (57), 2, 106-114.

Manshor, A. T., Fontaine, R., \& Chong, S. C. (2003). Occupational Stress among Managers: A Malaysian Survey. Journal of Managerial Psychology, 18, 622-628.

O’ Neill, P., \& Sohal, A. (1999). Business process reengineering - a review of recent literature. Technovation, (19), 9, 574.

Santos, J. R. A. (1999). Cronbach's alpha: A tool for assessing the reliability of scales. Journal of extension, 37(2), 1-5.

Sekaran, U. (2000). Research Methods for Business; A skill business approach. New York: John Willey \& Sons.

Selladurai, R. (2002). An organizational profitability, productivity, performance (PPP) model: Going beyond TQM and BPR. Total Quality Management Vol. 13(5) pp. 613-619 DOI: 10.1080/0954412022000002027. Retrieved from 
https://www.researchgate.net/publication/233176916_An_organizational_profitabilit Y_productivity_performance_PPP_model_Going_beyond_TQM_and_BPR

Stoddard, D. B., \& Jarvenpea, S. L. (1995). Business Process Redesign Tactics for Managing Radical Change, Journal of Management Information System 12(1): 91 - 103.

Sungau, J., Ndunguru, P. C., \& Kimem, J. (2013). The influence of Business Process reengineering on Service Quality: Evidence from Service Industry in Tanzania. Interdisciplinary Studies on Information Technology and Business (ISITB) Volume 1, Issue 1: pp. $83-83$. Retrieved from file://C:/Users/USER/Downloads/TheinfluenceofBusinessProcessreengineeringonServiceQuality_EvidencefromServiceIndustryinTanzania.pdf

Xiaoming, C., \& Junchen, Hu. (2012). A Literature Review on Organization Culture and Corporate Performance. International Journal of Business Administration, Vol. 3, No. 2. 